\title{
PASTA PACKAGING WITH BIO-BASED BARRIER TO PREVENT INSECT INFESTATION
}

\author{
Urška Vrabič Brodnjak ${ }^{1}$ (D), Pasquale Trematerra ${ }^{2}$ (D) \\ ${ }^{1}$ University of Ljubljana, Faculty of Natural Sciences and Engineering, Department of Textiles, \\ Graphic Arts and Design, Ljubljana, Slovenia \\ ${ }^{2}$ University of Molise, Department of Agricultural, Environmental and Food Sciences, \\ Campobasso, Italy
}

\begin{abstract}
The results of the infestation by maize weevil, Sitophilus zeamais (Coleoptera, Curculionidae) in various packages filled with pasta are presented. Three different types of packaging were used, i.e. two paper tubes (a novel one laminated with bio-based polyethylene and one without lamination) and a commercially available polypropylene pillow pouch packaging. Material properties such as moisture and water resistance and compressive strength were analysed. The results obtained showed that adult maize weevils revealed significant preferences to penetrate the pasta packaging through the already existing holes that were present in the polypropylene packaging, whereas no infestation was observed inside the paper tube packaging. The study showed that the shape and construction, e.g. tube packaging with an innovative bio-polyethylene film, is very effective against insect infestation and mechanical overload.
\end{abstract}

Key words: bio based polymer, S. zeamais, properties, paper tube, pillow pouch

\section{INTRODUCTION}

Recently, many researches have demonstrated that biodegradable plastic mixtures could be produced with certain limitations (Ramos et al, 2018; Yousefi et al, 2016; Hayes et al, 2019). Furthermore, postconsumer management and recyclability must be carefully managed. Biobased polyethylene (bio- PE) is presented as a suitable substitute due to its superior barrier properties (reduced permeability to $\mathrm{O} 2, \mathrm{CO} 2$ and water) and its higher heat resistance than polyethylene (PE) (Hayes et al, 2019; Briassoulis and Giannoulis, 2018; Luzi et al, 2019). Therefore, bio- PE has been frequently investigated in recent years (Ramos et al, 2018; Bandyopadhyay et al, 2019, Helanto et al, 2019). The production of bio- PE is mainly based on sugar cane, which is produced by chemical synthesis from renewable, biologically derived monomers (Ojha and Kapoor, 2018; Regubalan et al, 2019).

A major disadvantage of the existing packaging material is that insects infest the packaged food by penetrating it. Insect infestation depends on the pest species, exposure time, food, packaging material and prevailing environmental conditions. The solution to prevent infestation could be to use resistant laminated packaging that is both environmentally friendly and recyclable. Several insect species can infest pasta factories, which can have negative economic and commercial consequences. Infestation may occur during the storage process in production facilities, warehouses, general stores and retail outlets already colonised by insects derived from other products. Three species, i.e. S. zeamais Motschulsky, S. oryzae (L.) and S. granarius (L.) (Coleoptera Curculionidae), are most probably the most widespread and destructive primary pests of stored cereals. Pasta in particular can be infested by the corn weevil, S. zeamais, during transport in trucks, railway waggons and ships, and during storage at retail level or even in the consumer's home (Trematerra, 2009; Trematerra and Savoldelli, 2014; Stejskal et al, 2017). Adult corn beetles enter commercial pasta packaging through the openings made by other insects or through the existing openings caused by poor sealing or mechanical damage (Trematerra, 2009; Trematerra and Savoldelli, 2014; Stejskal et al, 2017). Most foods available on the market are packaged in a way that prevents infestation, although insect contamination is still common (Mullen et al, 2012; Heeps, 2016; Riudavets et al, 2018). Resistant and sealed packaging can be used to prevent infestation. Paper and cardboard packaging are the most common materials and are generally considered the most susceptible to insect infestation (Trematerra and Savoldelli, 2014). The widespread use of these susceptible food packaging materials should be carefully considered, as losses due to insect infestation in packaged food may be equivalent to the costs of cultivation, harvesting, transport, processing and packaging (Mullen et al, 2012; Heeps, 2016).

The aim of our work was to evaluate different packaging and to consider the possibility of using this packaging to better protect the food, in our case pasta, from insect attack. 


\section{MATERIALS AND METHODS}

\subsection{Materials}

\subsubsection{Packaging}

In this research, three different types of packaging were used: two unprinted paper tubes with and without a barrier film, and one commercial polypropylene packaging as presented in Table 1.

Table 1: Packaging characteristics

\begin{tabular}{|l|l|l|l|l|}
\hline Sample & Packaging & $\begin{array}{l}\text { Material } \\
\text { - outer base }\end{array}$ & $\begin{array}{l}\text { Material } \\
- \text { inner barrier }\end{array}$ & $\begin{array}{l}\text { Package dimension } \\
\text { [mm] }\end{array}$ \\
\hline $\begin{array}{l}\text { Sample A } \\
\text { not laminated }\end{array}$ & Paper tube & $\begin{array}{l}\text { Recycled kraft paper; } \\
\text { unprinted }\end{array}$ & $\begin{array}{l}\text { Recycled } \\
\text { kraft paper }\end{array}$ & $275.0 \times 65.7^{\text {a }}$ \\
\hline $\begin{array}{l}\text { Sample B } \\
\text { laminated }\end{array}$ & Paper tube & $\begin{array}{l}\text { Recycled kraft paper; } \\
\text { unprinted }\end{array}$ & $\begin{array}{l}\text { Laminated paper with bio- } \\
\text { Re film }\end{array}$ & $275.0 \times 65.7^{\text {a }}$ \\
\hline $\begin{array}{l}\text { Sample C } \\
\text { foil }\end{array}$ & $\begin{array}{l}\text { Plastic pillow pouch } \\
\text { with gussets and fin } \\
\text { seal }\end{array}$ & Polypropylene & No & $95 \times 304^{\text {b }}$ \\
\hline
\end{tabular}

a Length $\times$ diameter $(\varnothing)$ for paper tube packaging.

b Width $\times$ length for pouches, within the seals.

\subsubsection{Pasta products and olfactometer arena}

Pasta packages of durum wheat commercial spaghetti sample of 500 g, called "Spaghetti Ristorante 8" (produced by F. Divella S.p.A., Rutigliano, Bari, Italy) were used in the tests. The following nutritional information (average values) for $100 \mathrm{~g}$ was reported in the packages: energy $1508 \mathrm{KJ}$ (355 kcal), fats $1.7 \mathrm{~g}$ (of which saturated fats $0.9 \mathrm{~g}$ ), carbohydrates $72.0 \mathrm{~g}$ (of which sugars $3.9 \mathrm{~g}$ ), proteins $13.0 \mathrm{~g}$, salt $0.004 \mathrm{~g}$ (equivalent to sodium $1.6 \mathrm{mg}$ ). The tests were performed using 20 rectangular olfactometer arenas (each $30 \mathrm{~cm}$ wide, $40 \mathrm{~cm}$ long and $10 \mathrm{~cm}$ high). The tests were conducted at the temperature of $27 \pm 1^{\circ} \mathrm{C}$ with the relative humidity $(\mathrm{RH})$ of $70 \pm 5 \%$ and in dark conditions.

\subsection{Methods}

\subsubsection{Moisture content, water absorptiveness (Cobb value), capillary rise (Klemm method) and water} vapour transmission rate (WVTR)

Each paper tube packaging was tested for moisture content in accordance with ISO 287 at $105 \pm 1{ }^{\circ} \mathrm{C}$ and the results were expressed in percentage.

Water absorptiveness (Cobb60 value, $\mathrm{g} / \mathrm{m}^{2}$ ) was determined as described in the standard method ISO 535. Capillary rise was determined as described in ISO 8787 (ISO 8787: Paper and board -Determination of capillary rise - Klemm method).

Water vapour transmission rate (WVTR) was determined as described in the ISO 2528 standard method (ISO 2528: Determination of water vapour transmission rate (WVTR) - Gravimetric (dish) method).

\subsubsection{Compressive strength}

Compressive strength of paper tubes was determined with a pressurised plate, at which failure was determined. The test was performed on a tensile testing machine with the plate speed of $13 \mathrm{~mm} / \mathrm{min}$, standard atmosphere $23 \pm 1{ }^{\circ} \mathrm{C}$ and $50 \pm 2 \% \mathrm{RH}$. For each sample, five replicas were done as described in the ISO 12192:2011 standard. 


\subsubsection{Insect trials}

Unsexed, mixed-age, 1-2 week old adults obtained from the population of S. zeamais reared in a laboratory on durum wheat, with no history of exposure to insecticides, were used in all tests. This population was reared under the conditions of $27 \pm 1{ }^{\circ} \mathrm{C}$ and $70 \pm 5 \% \mathrm{RH}$. In each test, 50 S. zeamais adults were used. The experimental plan duration was 30 days.

Four different trial series were organised in arenas:

Trial 1: Sample A with $500 \mathrm{~g}$ of spaghetti inside +50 adults of S. zeamais.

Trial 2: Sample B with $500 \mathrm{~g}$ of spaghetti inside +50 adults of S. zeamais.

Trial 3: Sample A with $500 \mathrm{~g}$ of spaghetti inside + Sample $C+50$ adults of S. zeamais.

Trial 4: Sample B with $500 \mathrm{~g}$ of Spaghetti inside + Sample $C+50$ adults of S. zeamais.

Each trial was replicated 5 times (trial series), using a total of 1000 adults of S. zeamais (Figure 1). After 50 days, the adults that were outside were counted and the pasta packages were carefully examined, using a stereo microscope to check for the presence of both mechanical holes and holes due to the activity of insects. All packages were then opened and the adults inside the packages were counted.

\section{RESULTS AND DISCUSSION}

The permeation of water vapour through the packaging material influences the growth of microorganisms in food and damages the packaging material within a certain time. When selecting suitable materials for food packaging, it is important to analyze the moisture properties as shown in Table 2.

Table 2: Results of moisture properties of sample packaging

\begin{tabular}{|c|c|c|c|c|}
\hline Sample & $\begin{array}{c}\text { Moisture } \\
\text { content } \\
{[\%]}\end{array}$ & $\begin{array}{c}\text { Cobb } \\
\text { value } \\
{\left[\mathrm{g} / \mathrm{m}^{2}\right]}\end{array}$ & $\begin{array}{c}\text { Capillary } \\
\text { rise } \\
{[\mathrm{mm}]}\end{array}$ & $\begin{array}{c}\text { WVTR } \\
{\left[\mathrm{g} / \mathrm{m}^{2} \cdot \mathrm{day}\right]}\end{array}$ \\
\hline $\begin{array}{c}\text { Sample A } \\
\text { not } \\
\text { laminated }\end{array}$ & 10.1 & 2.15 & 54.2 & 3.52 \\
\hline $\begin{array}{c}\text { Sample B } \\
\text { laminated }\end{array}$ & 8.9 & 1.95 & 34.6 & 2.34 \\
\hline $\begin{array}{c}\text { Sample C } \\
\text { foil }\end{array}$ & 0.2 & 0.00 & 0.00 & 0.004 \\
\hline
\end{tabular}

It is necessary to consider the material's ability to absorb water (Cobb value), the amount of water vapour transmission rate (WVTR) transmitted through a unit area in time under a given temperature and relative humidity. Certain methods, such as capillary rise, help to determine where liquid, in our case water, rises by capillary action in a vertical strip of paper, cardboard. The results in Table 2 show that the PE film (sample C) has excellent resistance to water. On the other hand, the packaging of paper tubes with biofilm PE showed improved water resistance, especially with an average capillary rise of $19.6 \mathrm{~mm}$ compared to the non-laminated sample. The same trend could be observed for water vapour, where a decrease in transmission through the material by $1.18 \mathrm{~g} / \mathrm{m}^{2}$.day was observed. It is known that when paper comes into contact with water, hydrogen bonds between the fibers are broken and replaced by water bridge bonds. To protect fibre-fibre bonds and improve wet strength, lamination of board is one of the solutions. Laminations of bio- PE enhanced the moisture properties and mechanical properties shown below. 
Table 3: Results of tear and compressive strength of paper tube packaging

\begin{tabular}{|l|c|c|c|}
\hline Sample & $\begin{array}{c}\text { Tear strength } \\
{[\mathrm{mN}]}\end{array}$ & $\begin{array}{c}\text { Compressive } \\
\text { strength } \\
{[\mathrm{MPa}]}\end{array}$ & $\begin{array}{c}\text { Axial Young's } \\
\text { modulus } \\
{[\mathrm{GPa}]}\end{array}$ \\
\hline $\begin{array}{l}\text { Sample A } \\
\text { not laminated }\end{array}$ & 2100 & 10.13 & 2.07 \\
\hline $\begin{array}{l}\text { Sample B } \\
\text { laminated }\end{array}$ & 2300 & 11.75 & 2.47 \\
\hline
\end{tabular}

The compressive strength of the carton packaging depends on several factors, e.g. the weight of the carton and its contents, storage conditions, duration and transport conditions (stacking pattern, safety factor). The sample A achieved the tear strength of $2100 \mathrm{mN}$ and sample B $2300 \mathrm{mN}$.

The average compressive strength at the laminated paper tube was $16 \%$ higher. When exposed to the axial modulus of elasticity, it was also $2 \%$ higher on the laminated tube. This confirms that the packaging produced with spiral winding is durable and stable. If it is additionally laminated, the inner part is included and stability is increased (Figure 1).

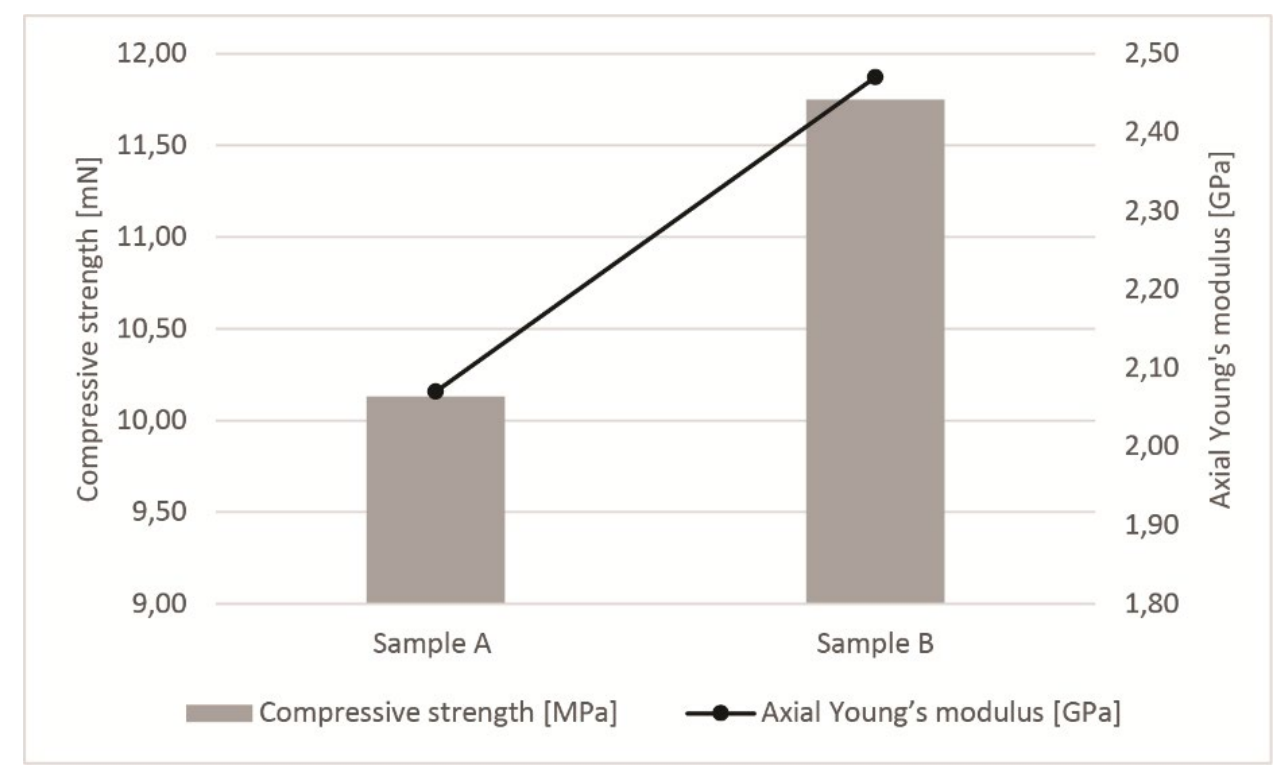

Figure 1: Compressive strength and Axial Young's modulus of sample $A$ and $B$

To check whether some insects have penetrated the commercial packaging, the samples were incubated to show the damage to the packaging. The final check was carried out after 50 days, which is the time required to complete the biological cycle of S. zeamais. The controls were carried out by opening each individual commercial package (sample C) before incubation. The observations on the package did not reveal any further damage to the polypropylene film. The observations made on the pasta did not show any damage caused by insect activity on the pasta itself. The results show that sample $A$ and sample $B$ were not attacked by insects (Table 4), while on sample C, i.e. the packaging of commercial pasta, attempts by insects to penetrate the packaging were observed, namely in the parts with transpiration micropores normally made on pasta packages.

The results show that Sample A and Sample B were not attacked by insects (Table 4), while in Sample C, i.e. the packaging of commercial pasta, attempts by insects to penetrate the packaging were observed in the parts with transpiration micropores normally found on pasta packaging (Figure 2). 
Table 4: Packaging effect regarding insect infestation.

\begin{tabular}{|c|c|c|c|c|c|c|c|}
\hline \multirow{2}{*}{ Test } & \multirow{2}{*}{$\begin{array}{l}\text { No of } \\
\text { dead } \\
\text { adults }\end{array}$} & \multicolumn{2}{|c|}{$\begin{array}{l}\text { Packaging } \\
\text { damage }\end{array}$} & \multicolumn{2}{|c|}{$\begin{array}{l}\text { Packaging } \\
\text { damage }\end{array}$} & \multirow{2}{*}{$\begin{array}{l}\text { Incubation } \\
\text { for } \\
50 \text { days }\end{array}$} & \multirow{2}{*}{$\begin{array}{l}\text { Check of } \\
\text { infestation } \\
\text { after } 50 \\
\text { days }\end{array}$} \\
\hline & & $\begin{array}{l}\text { Sample } \\
\text { A }\end{array}$ & $\begin{array}{l}\text { Sample } \\
\text { C }\end{array}$ & $\begin{array}{l}\text { Sample } \\
\text { B }\end{array}$ & $\begin{array}{l}\text { Sample } \\
\text { C }\end{array}$ & & \\
\hline \multirow{5}{*}{ Sample A + 50 insects } & 50 & No & - & - & - & - & - \\
\hline & 50 & No & - & - & - & - & - \\
\hline & 50 & No & - & - & - & - & - \\
\hline & 50 & No & - & - & - & - & - \\
\hline & 50 & No & - & - & - & - & - \\
\hline \multirow{5}{*}{ Sample B + 50 insects } & 47 & - & - & No & - & - & - \\
\hline & 49 & - & - & No & - & - & - \\
\hline & 50 & - & - & No & - & - & - \\
\hline & 50 & - & - & No & - & - & - \\
\hline & 49 & - & - & No & - & - & - \\
\hline \multirow{5}{*}{$\begin{array}{l}\text { Sample A + Sample C + } \\
50 \text { insects }\end{array}$} & 48 & No & Yes & - & - & - & - \\
\hline & 50 & No & No & - & - & - & - \\
\hline & 50 & No & Yes & - & - & $x$ & No \\
\hline & 50 & No & Yes & - & - & $x$ & No \\
\hline & 50 & No & Yes & - & - & $x$ & No \\
\hline \multirow{5}{*}{$\begin{array}{l}\text { Sample B + Sample C + } \\
50 \text { insects }\end{array}$} & 50 & - & - & No & Yes & $x$ & No \\
\hline & 50 & - & - & No & No & - & - \\
\hline & 50 & - & - & No & No & - & - \\
\hline & 49 & - & - & No & Yes & $x$ & No \\
\hline & 50 & - & - & No & Yes & $x$ & No \\
\hline
\end{tabular}

Damage caused by S. zeamais adults on sample C, packaging made of polypropylene pillow bags with side gussets and fin seal. In some cases only trials were found, in other cases the microholes were enlarged to allow the insects to enter the packaging (Figure 2).

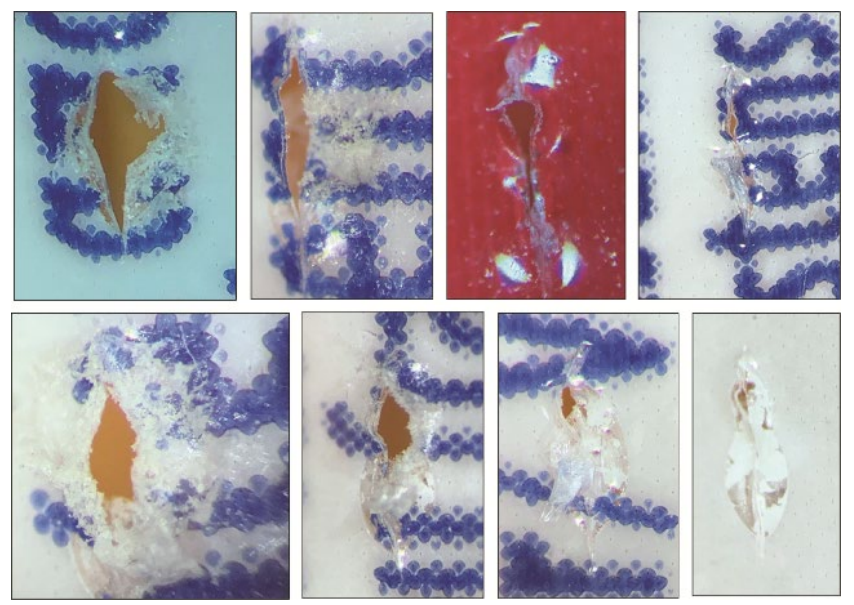

Figure 2: Damages produced by S. zeamais adults on Sample C, packages of polypropylene pillow pouch with gussets and fin seal

\section{CONCLUSIONS}

Infestation may occur during the storage process in production plants, warehouses, general stores and retail outlets already colonised by insects derived from other products, and in the home of the consumer.In polypropylene pasta packages, which had one or two rows of micro-holes with mechanical ventilation on the back, the holes facilitated the penetration of adult insects. The mechanical holes present in the packs allow the diffusion of volatile components that attract insects and facilitate the penetration of adult insects. When the holes were large enough, adult corn beetles penetrated without difficulty, while in other cases, clear signs of insect jawbone were observed, as determined in our tests. 
Packaged food products are susceptible to infestation along the entire marketing and supply chain channels, especially if the packaging is permeable to food odours.

To prevent insect infestation, the escape of food odours from the packaging can be prevented by the use of natural repellents or by the use of barrier materials. Our study found that materials and construction, e.g. paper tube packaging, are more effective against insect infestation compared to pillow bags, polypropylene packaging. In our case, no infestation was observed within the packaging of two different paper tubes without and with a biologically based PE barrier film. The paper tube with bio- PE achieved better mechanical and moisture properties; therefore, such packaging could be used for pasta products. Moreover, it can be refilled after the first use. The shelf life of the mentioned packaging is long compared to traditional polypropylene and other paper packaging on the market. Therefore, in order to obtain safer, healthier and higher quality food products, the lamination of paper tubes can be a more effective packaging for pasta products. An additional analysis should be carried out to determine the toxicological risk.

The risks of pasta contamination along the processing cycle, from the field raw material to the consumer, remain unclear due to specific aspects of carelessness in warehouses and shops and due to the long shelf life of the products. For these reasons it would be necessary to pay more attention to the packaging and the material used for packaging, which must be resistant to insect infestation.

\section{ACKNOWLEDGMENTS}

The authors are thankful to the Cost Action for Mathematical and Computer Science Methods for Food Science and Industry CA 15118 (FoodMC) for the support given in this research. The mention of trade names or commercial products in this publication is solely for providing specific information.

\section{REFERENCES}

[1] Bandyopadhyay, S., Saha, N., Brodnjak, U. V., Sáha, P.: "Bacterial cellulose and guar gum based modified PVP-CMC hydrogel films: Characterized for packaging fresh berries", Food Packaging and Shelf Life 22, 100402, 2019. doi: 10.1016/j.fpsl.2019.100402

[2] Briassoulis, D., Giannoulis, A.: "Evaluation of the functionality of bio-based food packaging films", Polymer Testing 69, 39-51, 2018. doi: 10.1016/j.polymertesting.2018.05.003

[3] Hayes, D. G., Anunciado, M. B., DeBruyn, J. M., Bandopadhyay, S., Schaeffer, S., English, M., Sintim, H. Y.: "Biodegradable plastic mulch films for sustainable specialty crop production", In: Polymers for Agri-Food Applications, (Springer, Cham, 2019.), pages 183-213.

[4] Heeps, J.: "Insect management for food storage and processing", (Elsevier, Amsterdam, 2016.)

[5] Helanto, K. E., Matikainen, L., Talja, R., Rojas, O. J.: "Bio-based Polymers for Sustainable Packaging and Biobarriers: A Critical Review", BioResources 14 (2), 4902-4951, 2019. doi: 10.15376/biores.14.2. Helanto

[6] Luzi, F., Torre, L., Kenny, J. M., Puglia, D.: "Bio-and fossil-based polymeric blends and nanocomposites for packaging: Structure-property relationship”, Materials 12 (3), 471, 2019. doi: 10.3390/ma12030471

[7] Mullen, M. A., Vardemann, J. M., Bagwell, J.: “Insect-Resistant Packaging", In: Stored Product Protection, Part II, Management: Prevention Methods, (Kansas State University, Manhattan KS, 2012.), pages 135-142.

[8] Ojha, S., Kapoor, S.: "Bio-Plastics: The Suitable and Sustainable Alternative to Polyethylene based Plastics", Microbiology 2, 145-148, 2019. doi: 10.31080/ASMI.2019.02.0254

[9] Ramos, Ó. L., Pereira, R. N., Cerqueira, M. A., Martins, J. R., Teixeira, J. A., Malcata, F. X., \& Vicente, A. A.: "Bio-based nanocomposites for food packaging and their effect in food quality and safety", In: Food Packaging and Preservation, (Academic Press, Cambridge MA, 2018.), pages 271-306.

[10] Regubalan, B., Pandit, P., Maiti, S., Nadathur, G. T., Mallick, A.: "Potential Bio-Based Edible Films, Foams, and Hydrogels for Food Packaging", In: Bio-based Materials for Food Packaging, (Springer, Singapore, 2018.), pages 105-123.

[11] Riudavets, J., Pons, M. J., Messeguer, J., Gabarra, R.: "Effect of CO2 modified atmosphere packaging on aflatoxin production in maize infested with Sitophilus zeamais", Journal of stored products research 77, 89-91, 2018. doi: 10.1016/j.jspr.2018.03.005 
[12] Stejskal, V., Bostlova, M., Nesvorna, M., Volek, V., Dolezal, V., Hubert, J.: "Comparison of the resistance of mono-and multilayer packaging films to stored-product insects in a laboratory test", Food control 73, 566-573, 2017. doi: 10.1016/j.foodcont.2016.09.001

[13] Trematerra, P.: "Preferences of Sitophilus zeamais to different types of Italian commercial rice and cereal pasta", Bulletin of Insectology 62, 103-106, 2009.

[14] Trematerra, P., Savoldelli, S.: "Pasta preference and ability to penetrate through packaging of Sitophilus zeamais Motschulsky (Coleoptera: Dryophthoridae)", Journal of Stored Products Research 59, 126-132, 2014. doi: 10.1016/j.jspr.2014.06.008

[15] Yousefi Shivyari, N., Tajvidi, M., Bousfield, D. W., \& Gardner, D. J.: "Production and characterization of laminates of paper and cellulose nanofibrils", ACS applied materials \& interfaces 8 (38), 25520-25528, 2016. doi: 10.1021/acsami.6b07655

(C) 2020 Authors. Published by the University of Novi Sad, Faculty of Technical Sciences, Department of Graphic Engineering and Design. This article is an open access article distributed under the terms and conditions of the Creative Commons Attribution license 3.0 Serbia (http://creativecommons.org/licenses/by/3.0/rs/). 